\title{
Taxonomy Diversity and Abundance of Seaweeds in the Northern Atlantic Coast of Senegal (West Africa)
}

Modou Fall GUEYE", Mame Samba MBAYE, Samba Laha KA, Jules DIOUF, Birane DIENG, Mamadou SIDYBE, Kandioura NOBA

Laboratoire de Botanique-Biodiversité, Département de Biologie Végétale, Faculté des Sciences et Techniques, Université Cheikh Anta DIOP, B.P.5005 Dakar-Fann, SENEGAL

Characterization and knowledge of the quantity of wild macroalgae stock available per season is necessary to allow the carrying out of a seaweed and exploitation project. The measurement of the quantity of seaweeds on the North coast was undertaken by the method of transects and quadrats. The inventory was carried out between 2017 and 2019 at 5 sites located on the said coast. In each site we have used Google Earth and the Arc Gis software predetermined 3 transects of $500 \mathrm{~m}$ each distant from $500 \mathrm{~m}$ to each other, arranged perpendicular to the coast. On each transect, sampling points spaced $50 \mathrm{~m}$ from each other with their coordinates have been pre-established. At each sampling point, 3 quadrats were fixed and the algae are harvested and identified. In this area, Ceramium rubrum var. pacificum is the most frequent species (5.8\% of the quadrats) and the most abundant but the Meristotheca senegalensis has the most important biomass with 1682 grams in 2017 and 1170 grams in 2018 harvested for each season in an area of 49,5 m2.

Keywords: Seaweeds, Senegal, Seasons, Frequency, Biomass, Abundance, Density.

Copyright ( 12020 The Author(s): This is an open-access article distributed under the terms of the Creative Commons Attribution 4.0 International License (CC BY-NC 4.0) which permits unrestricted use, distribution, and reproduction in any medium for non-commercial use provided the original author and source are credited.

\section{INTRODUCTION}

Macroalgae is a macroscopic algae living in the aquatic areas. They play an important role as primary producers and sources of food for marine organisms [30, $29,24]$. Economically, macroalgae are subject of several applications as an industrial raw material carrageenan, agar-agar, cosmetic, pharmaceutical, food sources, organic fertilizers, and others $[6,9,30,4,10]$. As part for over $80 \%$ of human food, macroalgae are used in the extraction of colloids (alginates, carrageenans and agars) [6]. According to [28], colloids production and human food represented respectively 43 and $47 \%$ of the tonnages of marine plants which is estimated of 7.6 million tons in 1994 and 90 among them is provided by cultivation. South-East Asia produces nearly $90 \%$ of the world's seaweed supplies for the manufacture of phyco-colloids [6]. Macroalgae represent a key functional group among the marine's ecosystems and perform vital ecological functions like reef structure stabilisation, nutrient retention and recycling, primary production in mangrove ecosystem, trophic support, shelter etc. [26, 12]. In Senegal, seaweed production along the Dakar coast is estimated from 08 to 10 tons of dry matter per year mainly intended for export to Japan [27].
Various studies of macroalgae have been carried out in some parts of Senegalese coast mainly in the Small Coast and Dakar Coast [8, 2, 23, 3, 19, 27, 22]. This research has predominantly focused on providing species "check lists". However, after the floristic composition, knowing the species dynamics, the abundance and the available stock of seaweed remain necessary before elaboration of any plan for a sustainable production. Furthermore, few studies on macroalgae have been conducted in the northern coast of Senegal known as the great coast despite their importance in Senegalese seaweed production.

The great Coast of Senegal is well documented in term of eco-biology, geomorphology and sedimentology due to the constant struggle against coastal erosion noted in this part of the Atlantic Ocean. Our research aims to study the distribution and abundance of macroalgae in northern coastal zone of Senegal and their dynamics and stock through the year.

\section{MATERIALS AND METHODS \\ Presentation of the study area}

Located at the western edge of West Africa, Senegal has a coastline length of $700 \mathrm{~km}$ with diverse 
coastal habitats which support rich seaweed biodiversity [17].

The great coast shares $250 \mathrm{~km}$ of the Senegal coastline from Dakar to Saint Louis and represents the northern part of the Atlantic Ocean [32]. It is known to harbour a rich diversity of seaweeds as its rocky segments provide suitable environment for macroalgal settlement and growth. It also shelters a great number of maritime fishing centers such as Saint-Louis, Loumpoul, Fass-Boye, Mboro, Kayar and Yoff [32].

The geomorphology of the north coast is sandy-muddy with alternations of rock bank from Yoff to Kayar. From Kayar to Saint Louis There is disappearing of the rock banks giving way to sand [16, 25].

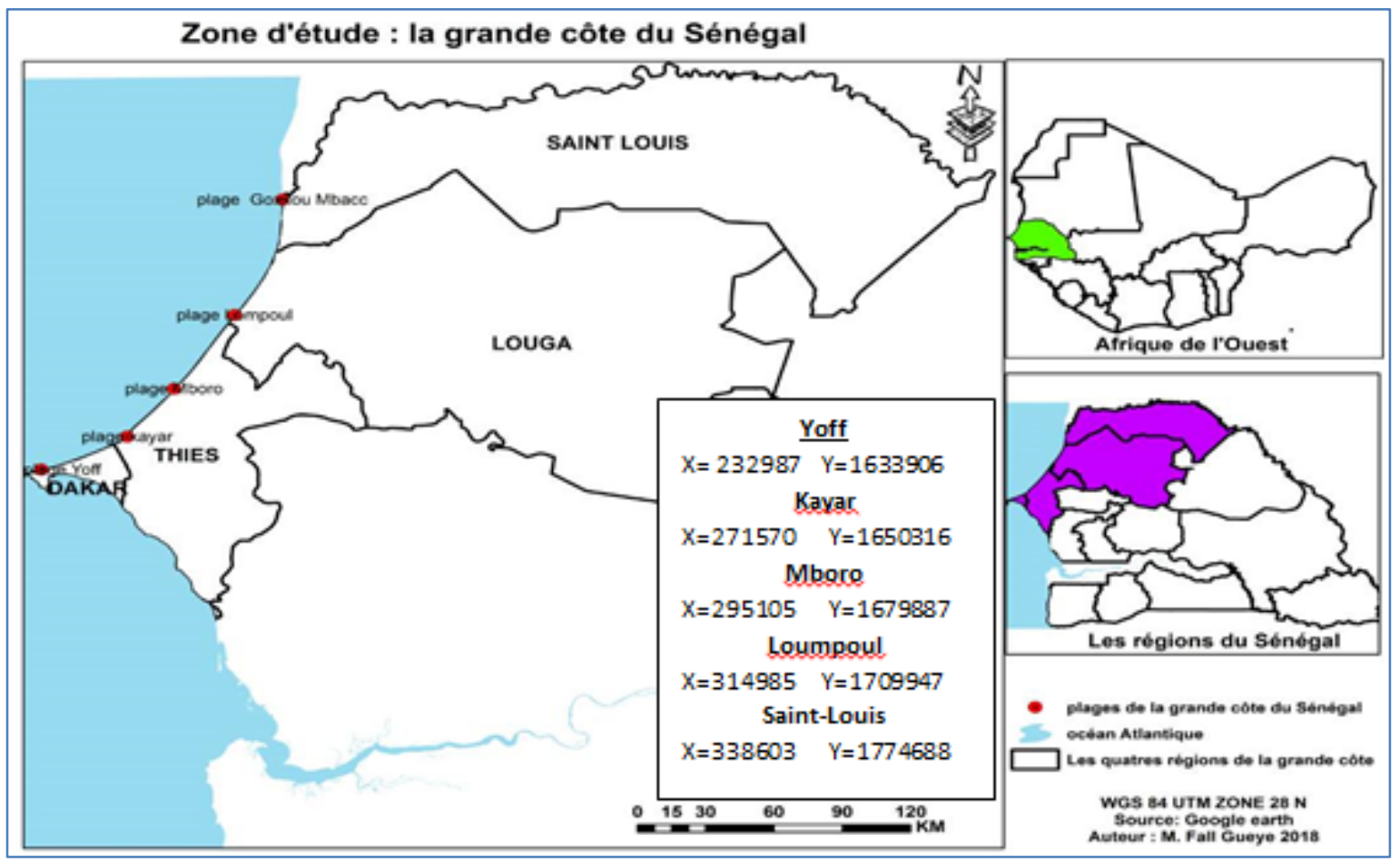

Fig-1: The great coast of Senegal or the North coast of Senegal (Yoff, Kayar, Mboro, Loumpoul and Saint-Louis)

\section{Experimental sites}

The study was carried out on the coast of Senegal because no study has existed so far on macroalgae. The survey areas were chosen according to the cantonment of the fishing docks in order to gain easy access to the canoes.

\section{Sampling}

The objective of the sampling was to characterize the flora of the area, study the dynamics of macroalgae and determine the available macroalgae stock.

\section{FIELD DATA COLLECTION AND ANALYSIS}

Field sampling of seaweeds/macroalgae

The study was conducted during two years from cold-season 2017 to warm-season 2019 in 5 stations along Senegalese northern coast. For quantitative assessment of the seaweeds in each site, the GPS-tagged, line intercept transects (LITs) were laid perpendicular to the coast in a seaward direction with the help of a $500 \mathrm{~m}$-long rope. 3 transects of $500 \mathrm{~m}$ each and $500 \mathrm{~m}$ apart were flagged and labelled using Google earth, GPS and ArcGIS software.

On each transect, 11 points spaced $50 \mathrm{~m}$ from one another with their coordinates have been established and in each of them, 3 tagged quadrats of $0.1 \mathrm{~m}^{2}(0.33 \mathrm{~m}$ $\mathrm{x} 0.33 \mathrm{~m}$ ) were fixed along the transects, i.e. 33 tagged quadrats (fig- 2 and 3 ). Therefore 99 quadrats and $9.9 \mathrm{~m}^{2}$ were explored for each campaign. A total of 495 quadrats were sampled for the seaweeds over a total of 15 transects on the Senegalese northern coast. 


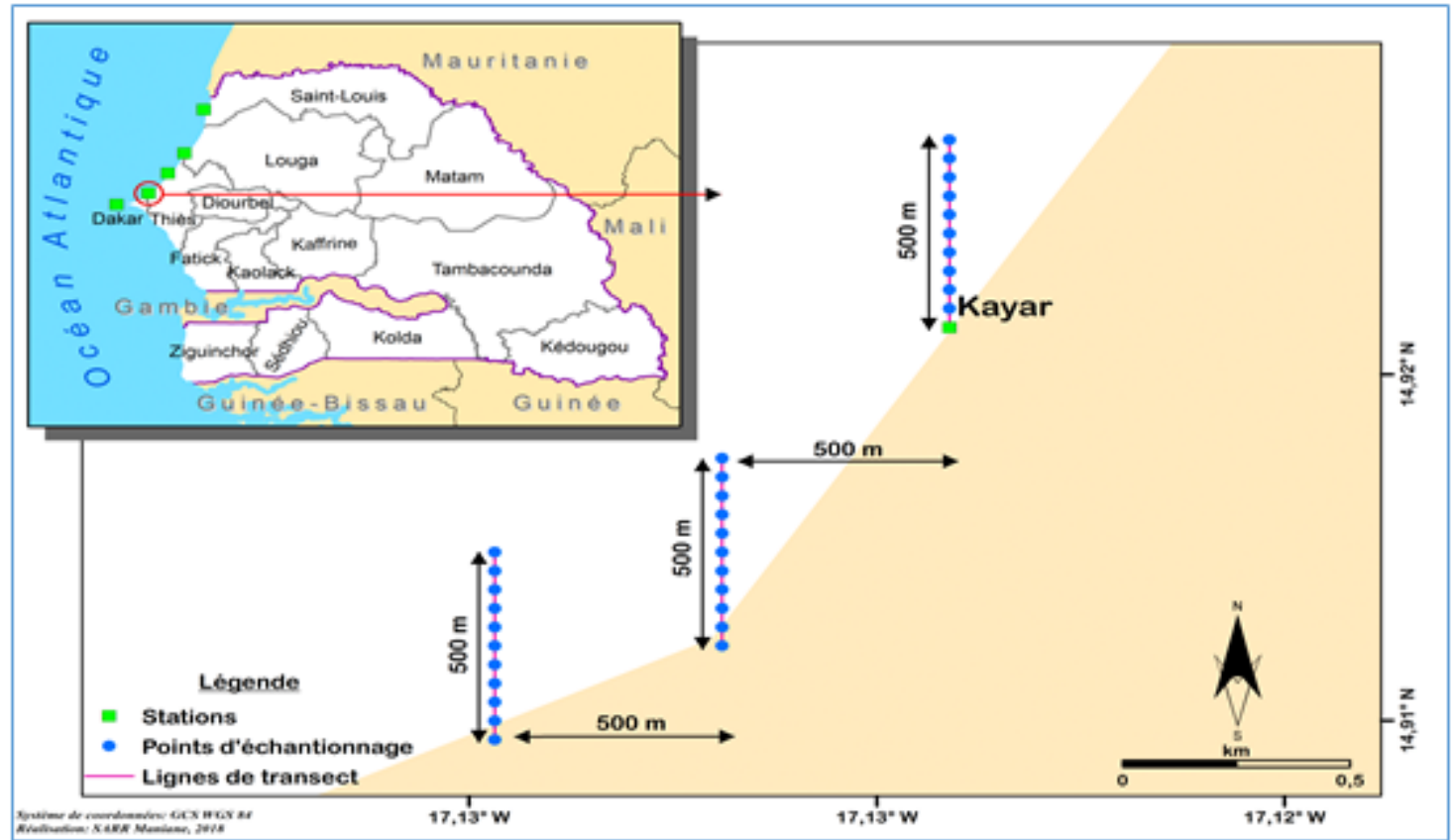

Fig-2: The sampling map along the northen coast of Senegal

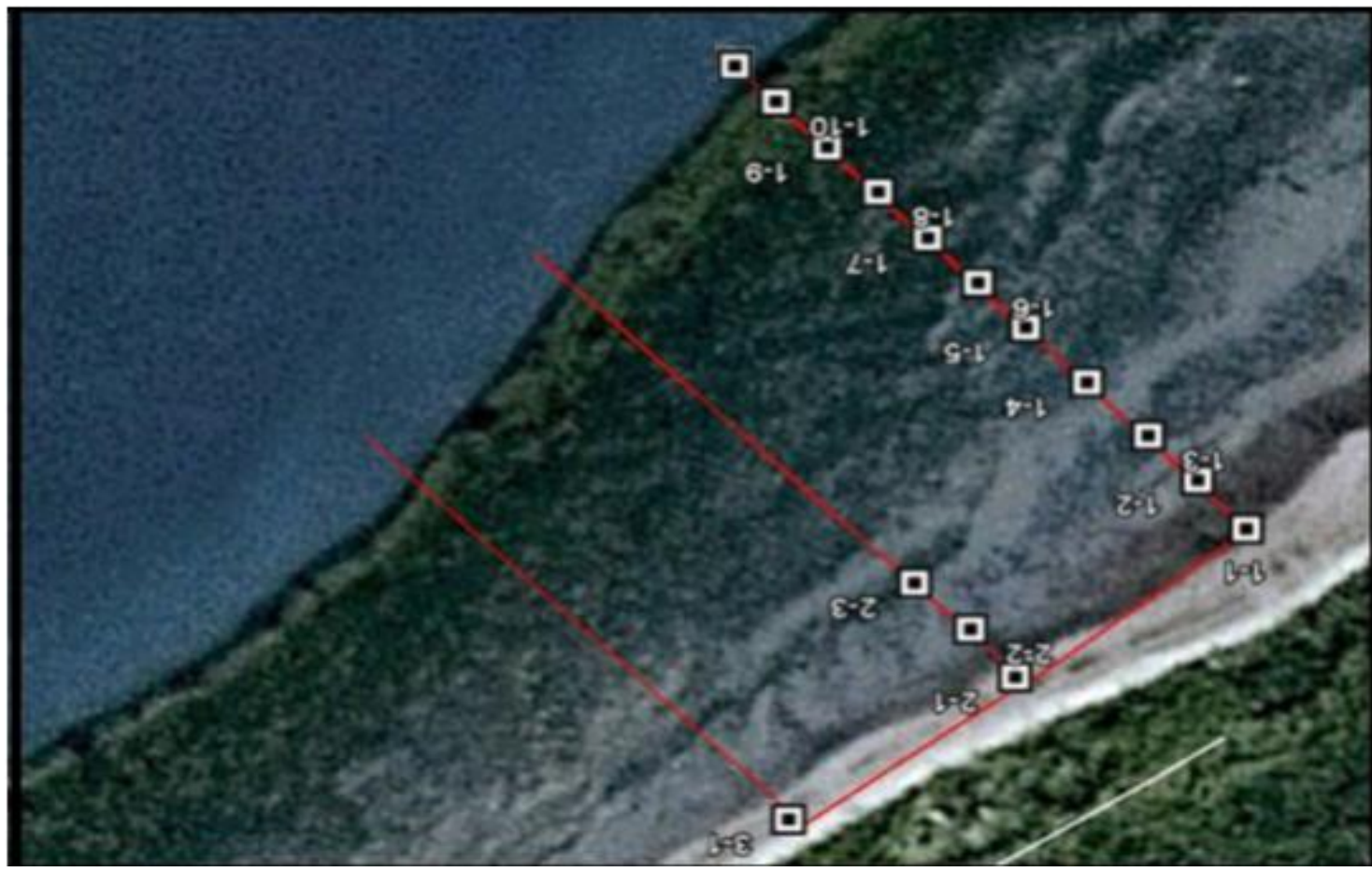

Fig-3: Illustration of the sampling device for a given site (in red: transects, $500 \mathrm{~m}$ apart from each other; in white: sampling points, $50 \mathrm{~m}$ apart along the same transect)

\section{Field data analysis}

Macroalgae samples collected from the quadrats were taken to laboratory for herbarium preparation, sample identification and quantitative assessment. Morphological criteria and reproductive structures of the algae specimens were analyzed for taxa identification.

\section{Sampling frequency}

Field survey was performed during two warm-seasons and two cold-seasons, ie 4 survey per site and 20 filed survey during two years (Table-1). During each field survey, the floristic list of macroalgae, the number of individuals per species and the dry matter of seaweed were recorded. 
Table-1: Sampling schedule for 5 sites in the North Coast

\begin{tabular}{|l|l|l|l|l|l|l|}
\hline \multirow{2}{*}{ Sites } & \multicolumn{2}{|l}{2017} & $\mathbf{2 0 1 8}$ & \multicolumn{2}{l|}{2019} \\
\cline { 2 - 7 } & CS & WS & CS & WS & CS & WS \\
\hline Yoff & - & July $07^{\text {th }}$ & 01 January & 14 August & 02 April & - \\
\hline Kayar & - & August $01^{\text {st }}$ & 03 January & 10 August & 06 April & - \\
\hline Mboro & - & September $05^{\text {th }}$ & 03 January & 15 August & 12 April & - \\
\hline Loumpoul & - & September $05^{\text {th }}$ & 30 March & 16 August & 13 April & - \\
\hline Saint-Louis & - & September $12^{\text {th }}$ & 29 March & 16 August & 14 April & - \\
\hline
\end{tabular}

CS (Cold Season), WS (Warm-Season)

\section{Sampling, measurements and methods}

On each sampling point, a square quadrat $(0.33$ $\times 0.33 \mathrm{~m}$ ) was randomly placed three times in each plot and seaweed in the square quadrat was collected. The remaining material was placed in a bag with holes and labels about ecology and biology characteristics of the quadrat (date and time of collection, general description of the habitat, the waypoint, the level of fixation on the rock, associated plants and animals...). In the laboratory, the samples are sorted, rinsed, wrung out and drained, and then the biomass was measured using an electronic balance. The number of individuals for each species except for crawling or grassy species is counted.

\section{Frequency of occurrence}

The frequency of occurrence of a species is the ratio of the number of the quadrat where the species is recorded out of the total number of square quadrats [7]. $\mathrm{F}=(\mathrm{Pa} / \mathrm{P}) \times 100$

$\mathrm{F}=$ Frequency of occurrence of the species. $\mathrm{Pa}$ $=$ total number of quadrats containing the species considered. $\mathrm{P}$ is the total number of quadrats. According to [7], the frequency of occurrence allows to distinct three types of species: constant species ( $\mathrm{F} \geq 50 \%$ ), accessory species $(25 \%<\mathrm{F}<50 \%)$, accidental species ( $\mathrm{F}$ $\leq 25 \%$ ).

\section{Relative abundance}

The relative abundance expressed a total number of individuals per species out of a total number of individuals of all species:

$$
\mathrm{A}=(\mathrm{Na} / \mathrm{Na}+\mathrm{Nb}+\mathrm{Nc}+\mathrm{N} \ldots) \times 100
$$

$\mathrm{A}=$ relative abundance of the species considered. $\mathrm{Na}$, $\mathrm{Nb}, \mathrm{Nc},=$ numbers of individuals of species $\mathrm{a}, \mathrm{b}, \mathrm{c}$.

The relative abundance provides information on the importance of each species compared to others.

The relative abundances by species were determined according to the grouping of algae into strata, or size categories, in order to draw up a precise picture of the vertical stratification of the populations.
The criteria used to determine the different vegetation strata are inspired by work in terrestrial phytosociology (see above), previously published work on macroalgae [33].

The representative size of a species at a given season, in a given site, corresponds to the average size observable in the most developed thalli. Each species, therefore, belongs to a single stratum for a given site. The algal strata taken into consideration are as follows:

- Stratum I (Caulacanthus, Caulerpa racemosa): encrusting individual or smaller than $0.5 \mathrm{~cm}$ in size and impossible to be counted.

- Stratum II (small Fucales, most green and red algae) individuals between 0.5 and $30 \mathrm{~cm}$ high:

- $\quad$ Stratum III (medium-sized fucales): individuals between 30 and $100 \mathrm{~cm}$ high

- Stratum IV (large Fucals, Laminariales): individuals over $100 \mathrm{~cm}$ high

In this part we have studied the abundance of stratum II because all the species encountered during this study except Caulacanthus ustulatus and Caulerpa racemosa var. peltata have heights between 0.5 and 30 $\mathrm{cm}$ and could be counted.

\section{Density}

The density of a stand is the number of living individuals of all species per unit area:

$\mathrm{D}=\mathrm{N} / \mathrm{S}$

$\mathrm{D}=$ Density of the species

$\mathrm{N}=$ Total number of individuals of a harvested species $\ll \mathrm{a} \gg$ in the stand considered.

$\mathrm{S}=$ Total area of quadrats sampled $\left(49.5 \mathrm{~m}^{2}\right.$ along the coast and $9.9 \mathrm{~m}^{2}$ each site).

Correlation coefficient between seaweed biomass and frequency was also estimated according to the linear equation. All statistical analyses were conducted using the $\mathrm{R} 3.5 .0$ software from $\mathrm{R}$ Development Core Team (2018) (Library Ade4, Agricolae and Vegan). 


\section{Biomass}

For the biomass assessment, the macroalgae samples taken from the sachets are once sorted in the laboratory, rinsed in fresh water, wrung out and drained and then weighed using a balance.

\section{RESULTS}

\section{Frequency of occurrence of macroalgae}

The frequency of occurrence of macroalgae on the northern coast of Senegal by season are shown in fig-4. Among the 12 recorded species, Meristotheca senegalensis, Ceramium rubrum var. pacificum, Caulacanthus ustulatus and Dictyota dichotoma are the most common species. The results showed that Meristotheca senegalensis was recorded in 5.2 and $2.9 \%$ of the square quadrats, respectively during 2017 and 2018 warm-season while the presence of Ceramium rubrum var. pacificum is noticed in $5.4 \%$ and $5.8 \%$ of quadrats at the same time. Caulacanthus ustulatus remains among the most frequent species and was recorded in $4.8 \%$ and $4.4 \%$ of quadrats respectively in cold-season 2018 and 2019 and $2.6 \%$ of the square quadrats during 2017 and 2018 warm-season. The species Dictyota dichotoma was one of the most frequents species during the warm season 2018 with $4.2 \%$ compared to 2019 warm-season where it appeared in $3 \%$ of square quadrats. The presence of Amphiroa sp, Gymnogongrus sp, Laurencia pinnatifida and L. obtusa was noticed under $1.2 \%$ of the quadrats which remained the lowest.

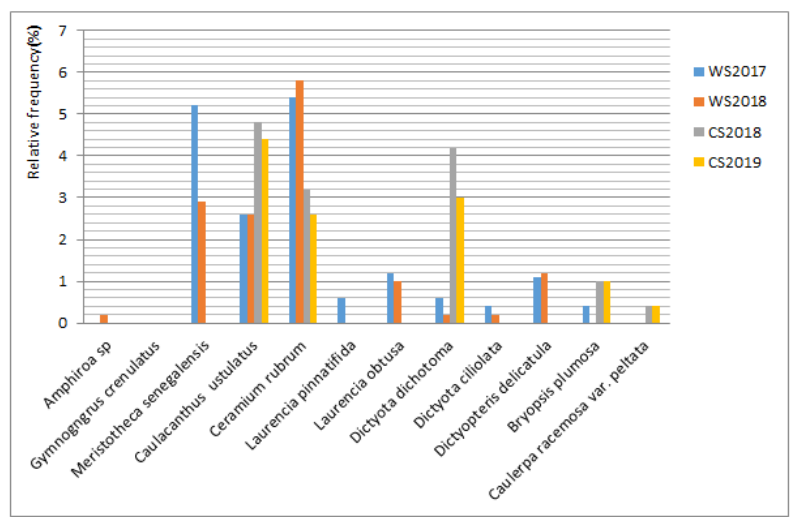

Fig- 4: Frequency of occurrence of macroalgae on the northern coast of Senegal by season

\section{Frequency of occurrence by site and by season}

The frequency of occurrence of macroalgae on the northern coast of Senegal by season and by site are shown in figure 5.

The results showed that the frequency of occurrence of each species was under $30 \%$ regardless of the collection site and the season. However, Meristotheca senegalensis, Caulacanthus ustulatus, Ceramium rubrum var. pacificum, Dictyota dichotoma were the most common species in square quadrats with frequencies between 10 and $29 \%$.
According to the locality, Ceramium rubrum var. pacificum was the most encountered species in Kayar with 29 and $27 \%$ of the quadrats respectively during the warm-seasons 2018 and 2017. At Yoff, Meristotheca senegalensis was the most common species and their presence was noticed in $26.2 \%$ and $14 \%$ of square respectively in warm-seasons 2017 and 2018. The presence of Dictyota dichotoma was exclusively registered at Yoff and it was more common during cold-season where it appeared in 21 and 15 of square quadrats respectively in 2018 and 2019. Caulacanthus ustulatus is a common species in Yoff as well as in Kayar. It was recorded in 20 and $19 \%$ of square quadrats respectively during cold season 2018 and 2019 and in $13 \%$ of square quadrats respectively in 2017 and 2018 warm-season. The following species: Amphiroa sp, Gymnogongrus sp, Laurencia pinnatifida, L. obtusa, Dictyota ciliolata, Dictyopteris delicatula, Bryopsis plumose and Caulerpa racemosa var. peltata) were found at Yoff coast but with à low proportion under $6 \%$ of square quadrats. This study also revealed that any species was registered in three locations (Mboro, Loumpoul and Saint-Louis).

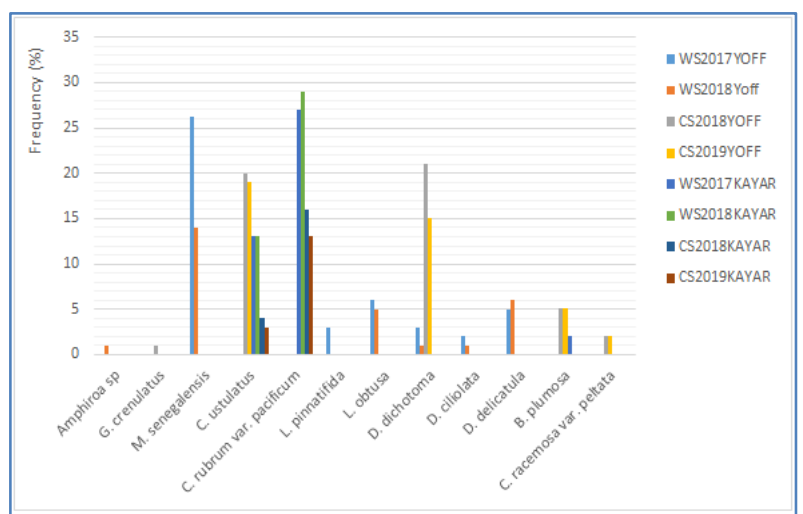

Fig- 5: Frequency of occurrence of macroalgae by site and by season

\section{Abundance and density of species on the North Coast Relative abundance of North Coast macroalgae by season}

The abundance of species varies with the seasons. The field survey showed that Ceramium rubrum var. pacificum and Dictyota dichotoma were the most abundant species through the years. Ceramium rubrum var. pacificum represented 53\%,62\%, 34 and $43 \%$ of total emerged species respectively in warm-season 2017 and 2018 and in cold-season 2018 and 2019. Dictyota dichotoma was also dominant in 2018 and 2019 cold-season with 56 and $49 \%$ of harvested individuals while it appeared under one percent of species recorded in square quadrats during the warm-seasons. Except for Dictyopteris delicatula which constituted $18 \%$ of individuals recorded in the warm-season 2018, the presence of others species remained low under $10 \%$ of total individuals (table- 2 ). 
Table- 2: Relative abundance $(\%)$ of macroalgae from the North Coast by season

\begin{tabular}{|l|l|l|l|l|}
\hline Specie & $\begin{array}{l}\text { Ar WS2017 } \\
(\%)\end{array}$ & $\begin{array}{l}\text { Ar WS2018 } \\
(\%)\end{array}$ & $\begin{array}{l}\text { Ar CS2018 } \\
(\%)\end{array}$ & $\begin{array}{l}\text { Ar CS2019 } \\
(\%)\end{array}$ \\
\hline Amphiroa sp & 0 & 2,4 & 0 & 0 \\
\hline Gymnogongrus crenulatus & 0 & 0 & 2,6 & 0 \\
\hline Meristotheca senegalensis & 12 & 4 & 0 & 0 \\
\hline Ceramium rubrum var. pacificum & 52,6 & 61,7 & 33,8 & 43,1 \\
\hline Laurencia pinnatifida & 6,5 & 0 & 0 & 0 \\
\hline Laurencia obtusa & 7,9 & 7,5 & 0 & 0 \\
\hline Dictyota dichotoma & 7,6 & 3 & 56,3 & 48,8 \\
\hline Dictyota ciliolata & 4,2 & 3,2 & 0 & 0 \\
\hline Dictyopteris delicatula & 7 & 18 & 0 & 0 \\
\hline Bryopsis plumosa & 1,5 & 0 & 7 & 8 \\
\hline Abondance absolue cumulées & $\mathbf{8 3 8}$ & $\mathbf{7 0 4}$ & $\mathbf{6 3 5}$ & $\mathbf{4 7 3}$ \\
\hline
\end{tabular}

Ar WC $=$ Relative abundance in Warm-Season. Ar CS = Relative abundance Cold Season

Relative abundance of stratum II macroalgae by site and by season

\section{Relative abundance of macroalgae in Yoff}

Fig- 6 shows the relative abundance of macroalgae depending on sites and seasons. During the filed survey at Yoff a total of 384, 269, 420 and 269 individuals were recorded respectively during warm-seasons 2017 and 2018 and cold-seasons 2018 and 2019. In the warm season 2017, Meristotheca senegalensis and Laurencia obtusa were the most abundant species with respectively $26.5 \%$ and $17.4 \%$ of the 384 individuals recorded. In 2018 warm season, Dictyopteris delicatula were the dominant species with $47.21 \%$ of individuals.

Dictyota dichotoma was the most abundant species during the cold seasons 2018 and 2019 with respectively 85 and $86 \%$ of individuals recorded. The presence of the other species were low regardless of period or location.

\section{Relative abundance of macroalgae in Kayar}

During the filed survey at Kayar a total of 454, 435, 215 and 204 individuals were collected respectively during warm-seasons 2017 and 2018 and cold-seasons 2018 and 2019. In the warm-season 2017.

The fig-6 showed that Ceramium rubrum var. pacificum was the only species recorded during the cold seasons and the warm season 2017 while it constituted 97\% of individuals encountered in 2017 warm season.

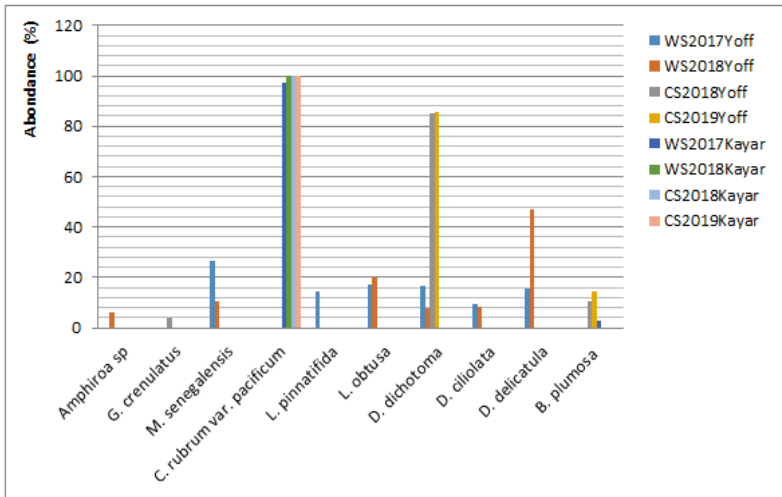

Fig-6: Relative abundance of macroalgae from stratum II by site and by season

\section{Density of macroalgae in stratum II by season}

The density of macroalgae in stratum II of the Northern Coast of Senegal per season was presented in table-3. The study showed that Ceramium rubrum var. pacificum had a highest density in 2017 and 2018 with respectively 9.0 and 8.7 individuals per $\mathrm{m}^{2}$ during warm-seasons. It was followed by Dictyopteris delicatula with 2.5 ind. $\mathrm{m}^{2}$ in 2018 and Meristotheca senegalensis with 2.5 ind. $\mathrm{m}^{2}$ in 2017. In 2018 and 2019 cold-seasons Dictyota dichotoma had the highest density with respectively 7.23 and 4.6 individuals per $\mathrm{m}^{2}$. It was followed by Ceramium rubrum var. pacificum with individuals per $\mathrm{m}^{2}$ in 2018 and 4.1 individuals per $\mathrm{m}^{2}$ in 2019.

Table- 3: The density of macroalgae taxa from the North Coast by season

\begin{tabular}{|l|l|l|l|l|}
\hline & $\begin{array}{l}\text { WS2017 } \\
\mathbf{D}\left(\mathbf{i n d} / \mathbf{m}^{\mathbf{2}}\right)\end{array}$ & $\begin{array}{l}\text { WS2018 } \\
\mathbf{D}\left(\mathbf{i n d} / \mathbf{m}^{\mathbf{2}}\right)\end{array}$ & $\begin{array}{l}\mathbf{C S 2 0 1 8} \\
\mathbf{D}\left(\mathbf{i n d} / \mathbf{m}^{\mathbf{2}}\right)\end{array}$ & $\begin{array}{l}\mathbf{C S 2 0 1 9} \\
\mathbf{D}\left(\mathbf{i n d} / \mathbf{m}^{\mathbf{2}}\right)\end{array}$ \\
\hline Amphiroa sp & 0 & 0,3 & 0 & 0 \\
\hline Gymnogongrus crenulatus & 0 & 0 & 0,3 & 0 \\
\hline Meristotheca senegalensis & 2 & 0,5 & 0 & 0 \\
\hline Ceramium rubrum var. pacificum & 9 & 8,7 & 4,3 & 4,1 \\
\hline Laurencia pinnatifida & 1 & 0 & 0 & 0 \\
\hline Laurencia obtusa & 1,3 & 1 & 0 & 0 \\
\hline Dictyota dichotoma & 1,2 & 0,4 & 7,23 & 4,6 \\
\hline Dictyota ciliolata & 0,7 & 0,4 & 0 & 0 \\
\hline Dictyopteris delicatula & 1,2 & 2,5 & 0 & 0 \\
\hline Bryopsis plumosa & 0,2 & 0 & 0,9 & 0,76 \\
\hline
\end{tabular}


Density of macroalgae in stratum II by site and by season

The fig- 7 showed the density of macroalgae in number of individuals per square meter per season.

\section{Density of macroalgae in Yoff}

During the warm season 2017, Meristotheca senegalensis had the highest density with 10.3 ind. $\mathrm{m}^{2}$ followed by Laurencia obtusa (6.7 ind. $\left.\mathrm{m}^{2}\right)$, Dictyota dichotoma (6.4 ind. $\left.\mathrm{m}^{2}\right)$, Dictyopteris delicatula (6 ind. $\left.\mathrm{m}^{2}\right)$, Laurencia pinnatifida $\left(5\right.$ ind. $\left.\mathrm{m}^{2}\right)$ and Dictyota ciliolata (3.6 ind. $\mathrm{m}^{2}$ ). In 2018 warm season, the flora was dominated by Dictyopteris delicatula (12.8 ind. $\left.\mathrm{m}^{2}\right)$ followed by Laurencia obtusa (5.3 ind. $\left.{ }^{2}\right)$, Meristotheca senegalensis (2.8 ind. $\left.\mathrm{m}^{2}\right)$, Dictyota ciliolata (2.3 ind. $\left.\mathrm{m}^{2}\right)$, Dictyota dichotoma (2.1 ind. $\left.\mathrm{m}^{2}\right)$ and Amphiroa sp (1.7 ind. $\left.\mathrm{m}^{2}\right)$.

During 2018 and 2019 cold seasons, Dictyota dichotoma had the highest density with respectively 36 and 23 ind. $\mathrm{m}^{2}$.

\section{Density of macroalgae in Kayar}

Except for Bryopsis plumose (1.3 ind. ${ }^{2}$ ) recorded during the warm-season 2017, the flora was exclusively represented by Ceramium rubrum var. pacificum with 44.5 ind / $\mathrm{m} 2$ in the warm-season 2017 , 43.9 ind. $\mathrm{m}^{2}$ in warm season $2018,21.7$ ind. $\mathrm{m}^{2}$ in the cold season 2018 and 20.6 ind. $\mathrm{m}^{2}$ in the cold-season 2019 (fig- 7).

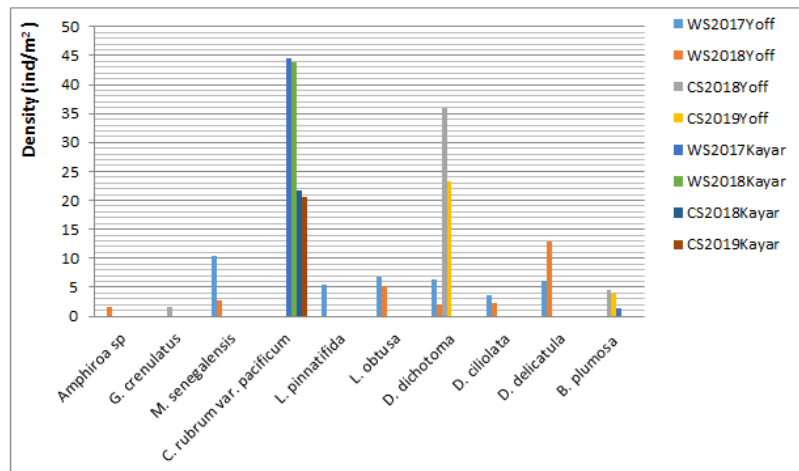

Fig-7: Density of macroalgae in stratum II by site and by season

The biomass and density of macroalgae from the northern coast of Senegal

Biomass and total density of macroalgae from the North coast by season. Seaweed biomass and density from the northern coast of Senegal are shown in figure 8 .

The highest macroalgae biomass was obtained during the warm season 2017 with $2329.5 \mathrm{~g}$ and a density of 47 ind. $\mathrm{m}^{2}$. In 2018 warm season a quantity of $1745.1 \mathrm{~g}$ with a density of 35.2 ind. $\mathrm{m}^{2}$ was collected. A quantity of 975.3 and $976.3 \mathrm{~g}$ of seaweed were harvested respectively during 2018 and 2019 warm season.

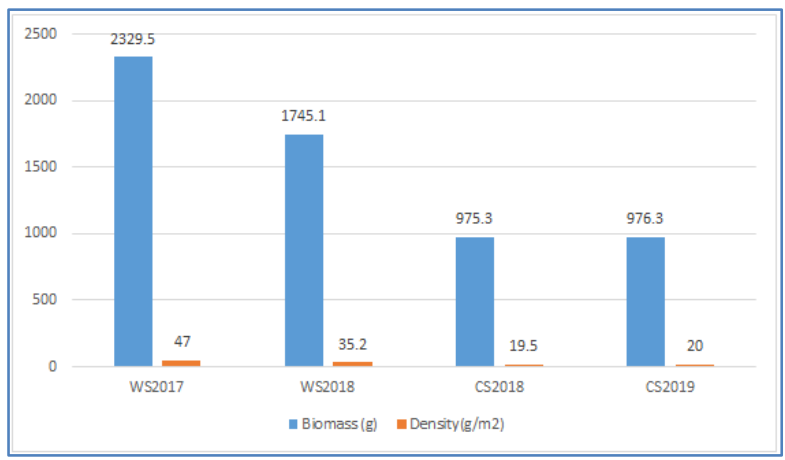

Fig-7: Biomass and total density of macroalgae on the North Coast by season and by site

The results of the study showed that the macroalgae were affected by the season. The highest seaweed biomass was obtained during the warm-season. Besides, the quantity of seaweed biomass collected at Yoff was greater compared to Kayar regardless of the period (fig- 9).

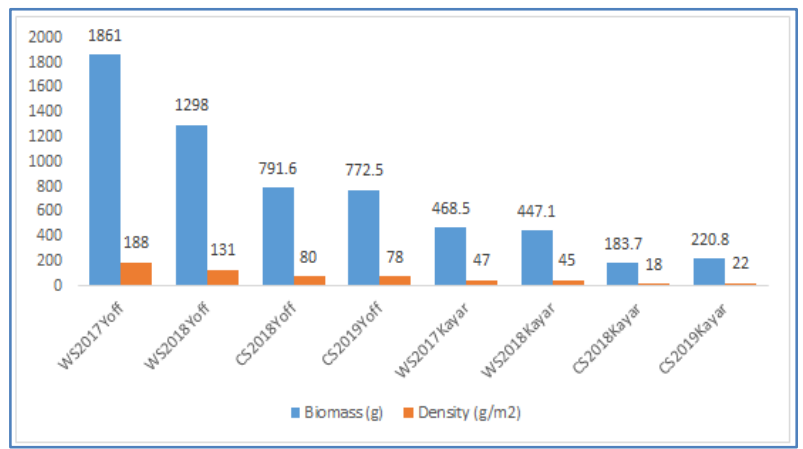

Fig-9: Biomass and total density of macroalgae on the North Coast by season and by site

Biomass of macroalgae species on the North Coast by season are given in table- 4. Meristotheca senegalensis had the highest biomass with 1682 and 1170 respectively during the warm-season 2017 and 2018. It was followed by Ceramium rubrum var. pacificum with 355.1 and 338.3 g. During the cold-season 2018 and 2019, the highest value of biomass was recorded for Caulacanthus ustulatus with respectively 535 and 583g. In 2018 and 2019 warm-season, 167 and $161 \mathrm{~g}$ were registered for Ceramium rubrum var. pacificum. 
Table-4: Biomass (g) of macroalgae from the northern coast of Senegal by season

\begin{tabular}{|l|l|l|l|l|}
\hline & $\begin{array}{l}\text { WS2017 } \\
\text { B(g) }\end{array}$ & $\begin{array}{l}\text { WS2018 } \\
\text { B(g) }\end{array}$ & $\begin{array}{l}\text { CS2018 } \\
\text { B(g) }\end{array}$ & $\begin{array}{l}\text { CS2019 } \\
\text { B(g) }\end{array}$ \\
\hline Amphiroa sp & 0 & 6 & 0 & 0 \\
\hline Gymnogongrus crenulatus & 0 & 0 & 4,1 & 0 \\
\hline Meristotheca senegalensis & 1682 & 1170 & 0 & 0 \\
\hline Caulacanthus ustulatus & 108,4 & 108,8 & 535,4 & 583 \\
\hline Ceramium rubrum var. pacificum & 355,1 & 338,3 & 167,4 & 160,5 \\
\hline Laurencia pinnatifida & 29 & 0 & 0 & 0 \\
\hline Laurencia obtusa & 66 & 57 & 0 & 0 \\
\hline Dictyota dichotoma & 29 & 9 & 134,1 & 90,8 \\
\hline Dictyota ciliolata & 16 & 9 & 0 & 0 \\
\hline Dictyopteris delicatula & 39 & 47 & 0 & 0 \\
\hline Bryopsis plumosa & 5 & 0 & 14,3 & 12 \\
\hline Caulerpa racemosa var. peltata & 0 & 0 & 120 & 130 \\
\hline
\end{tabular}

Density of macroalgae on the northern coast of Senegal by season

In each year during the warm season 2017 and 2018 the highest density was recorded for Meristotheca senegalensis with respectively 34 and 23.6 g.m². It was followed by Ceramium rubrum var. pacificum with 7 and 6.8 g.m ${ }^{2}$ respectively in 2017 and 2018 warm season.
Our results also showed that Caulacanthus ustulatus had the greatest density in the cold season 2018 and 2019 with respectively 10.8 and 11.7 g.m². The density of other species (Amphiroa sp, Gymnogongrus crenulatus, Laurencia pinnatifida, Laurencia obtusa, Dictyota dichotoma, Dictyota ciliolata, Dictyopteris delicatula, Bryopsis plumosa and Caulerpa racemosa var. peltata) remained low under $3.3 \mathrm{~g} . \mathrm{m}^{2}$.

Table-5: Density ( $\mathrm{g} / \mathrm{m} 2)$ of macroalgae from the northern Coast of Senegal by season

\begin{tabular}{|l|l|l|l|l|}
\hline & $\begin{array}{l}\text { WS2017 } \\
\left(\mathbf{g} / \mathbf{m}^{\mathbf{2}}\right)\end{array}$ & $\begin{array}{l}\mathbf{W S 2 0 1 8} \\
\left(\mathbf{g} / \mathbf{m}^{\mathbf{2}}\right)\end{array}$ & $\begin{array}{l}\mathbf{C S 2 0 1 8} \\
\left(\mathbf{g} / \mathbf{m}^{\mathbf{2}}\right)\end{array}$ & $\begin{array}{l}\mathbf{C S 2 0 1 9} \\
\left(\mathbf{g} / \mathbf{m}^{\mathbf{2}}\right)\end{array}$ \\
\hline Amphiroa sp & 0 & 0,1 & 0 & 0 \\
\hline Gymnogongrus crenulatus & 0 & 0 & 0,08 & 0 \\
\hline Meristotheca senegalensis & 34 & 23,6 & 0 & 0 \\
\hline Caulacanthus ustulatus & 2 & 2,1 & 10,8 & 11,7 \\
\hline Ceramium rubrum var. pacificum & 7 & 6,8 & 3,3 & 3,2 \\
\hline Laurencia pinnatifida & 0,5 & 0 & 0 & 0 \\
\hline Laurencia obtusa & 1,3 & 1,1 & 0 & 0 \\
\hline Dictyota dichotoma & 0,5 & 0,1 & 2,7 & 1,8 \\
\hline Dictyota ciliolata & 0,3 & 0,1 & 0 & 0 \\
\hline Dictyopteris delicatula & 0,7 & 0,9 & 0 & 0 \\
\hline Bryopsis plumosa & 0,1 & 0 & 0,2 & 0,2 \\
\hline Caulerpa racemosa var. peltata & 0 & 0 & 2,4 & 2,6 \\
\hline
\end{tabular}

Biomass and density of macroalgae by site and season in the northern coast of Senegal

Biomass and density of macroalgae in Yoff by season

At Yoff, Meristotheca senegalensis was the most important species in term of biomass (1682 g) and density (169.8g.m²) during the warm season 2017. During the cold season, the highest biomass and density were recorded for Caulacanthus ustulatus with respectively $519.1 \mathrm{~g}$ and $52.4 \mathrm{~g} . \mathrm{m}^{2}$ in 2018 and $539.7 \mathrm{~g}$ or 54.4 g. $\mathrm{m}^{2}$ in 2019.

Table-6: Biomass and density of macroalgae in Yoff by season

\begin{tabular}{|l|l|l|l|l|l|l|l|l|}
\hline & WS2017Yoff & WS2018Yoff & \multicolumn{2}{l|}{ CS2018Yoff } & \multicolumn{2}{l|}{ CS2019Yoff } \\
\cline { 2 - 9 } & $\mathrm{B}(\mathrm{g})$ & $\mathrm{D}(\mathrm{g} / \mathrm{m} 2)$ & $\mathrm{B}(\mathrm{g})$ & $\mathrm{D}(\mathrm{g} / \mathrm{m} 2)$ & $\mathrm{B}(\mathrm{g})$ & $\mathrm{D}(\mathrm{g} / \mathrm{m} 2)$ & $\mathrm{B}(\mathrm{g})$ & $\mathrm{D}(\mathrm{g} / \mathrm{m} 2)$ \\
\hline Amphiroa sp & 0 & 0 & 6 & 0,6 & 0 & 0 & 0 & 0 \\
\hline Gymnogongrus crenulatus & 0 & 0 & 0 & 0 & 4,1 & 0,4 & 0 & 0 \\
\hline Meristotheca senegalensis & 1682 & 169,8 & 1170 & 118,1 & 0 & 0 & 0 & 0 \\
\hline Caulacanthus ustulatus & 0 & 0 & 0 & 0 & 519,1 & 52,4 & 539,7 & 54,4 \\
\hline Laurencia pinnatifida & 29 & 2,9 & 0 & 0 & 0 & 0 & 0 & 0 \\
\hline Laurencia obtusa & 66 & 6,6 & 57 & 5,7 & 0 & 0 & 0 & 0 \\
\hline Dictyota dichotoma & 29 & 2,9 & 9 & 0,9 & 134,1 & 13,5 & 90,8 & 9,1 \\
\hline Dictyota ciliolata & 16 & 1,6 & 9 & 0,9 & 0 & 0 & 0 & 0 \\
\hline Dictyopteris delicatula & 39 & 3,9 & 47 & 4,7 & 0 & 0 & 0 & 0 \\
\hline Bryopsis plumosa & 0 & 0 & 0 & 0 & 14,3 & 1,4 & 12 & 1,2 \\
\hline Caulerpa racemosa var peltata & 0 & 0 & 0 & 0 & 120 & 12,1 & 130 & 13,1 \\
\hline
\end{tabular}


The biomass and density of macroalgae in Kayar by season

The table- 7 showed the biomass and density of seaweed by season and site.

In Kayar, Ceramium rubrum var. pacificum and Caulacanthus ustulatus had the highest biomass and density while the presence of Bryopsis plumosa remained low and where only noticed during the 2017 warm season. The results also showed that the biomass of Caulacanthus ustulatus was more important during the cold seasons compared to warm seasons. Their density was 35.8 g.m ${ }^{2}$ and 34 g.m $\mathrm{m}^{2}$ respectively in 2017 and 2018 warm season and 16.9 g.m ${ }^{2}$ and 16.2 g.m ${ }^{2}$ respectively in 2018 and 2019 cold season. It appeared also that Meristotheca senegalensis was the most abundant species in Yoff while Ceramium rubrum var. pacificum was the most important.

Table-7: The biomass and density of macroalgae in Kayar by season

\begin{tabular}{|l|l|l|l|l|l|l|l|l|l|}
\hline \multirow{2}{*}{ Caulacanthus ustulatus } & WS2017KAYAR & WS2018KAYAR & \multicolumn{2}{l|}{ CS2018KAYAR } & CS2019KAYAR \\
\cline { 2 - 9 } & $\mathrm{B}(\mathrm{g})$ & $\mathrm{D}\left(\mathrm{g} / \mathrm{m}^{2}\right)$ & $\mathrm{B}(\mathrm{g})$ & $\mathrm{D}\left(\mathrm{g} / \mathrm{m}^{2}\right)$ & $\mathrm{B}(\mathrm{g})$ & $\mathrm{D}\left(\mathrm{g} / \mathrm{m}^{2}\right)$ & $\mathrm{B}(\mathrm{g})$ & $\mathrm{D}\left(\mathrm{g} / \mathrm{m}^{2}\right)$ \\
\hline Ceramium rubrum var. pacificum & 108,4 & 10,9 & 108,8 & 10,9 & 16,3 & 1,6 & 43,3 & 4,3 \\
\hline Bryopsis plumosa & 355,1 & 35,8 & 338,3 & 34 & 167,4 & 16,9 & 160,5 & 16,2 \\
\hline
\end{tabular}

\section{Relationship between Biomass and the abundance of macroalgae}

The study of linear correlation between the seaweed biomass and their abundance showed that the biomass was not significantly affected by the seaweed density with a correlation coefficient of $0.23(r=0.23)$. Fig- 10 Correlation between seaweed biomass and abundance.

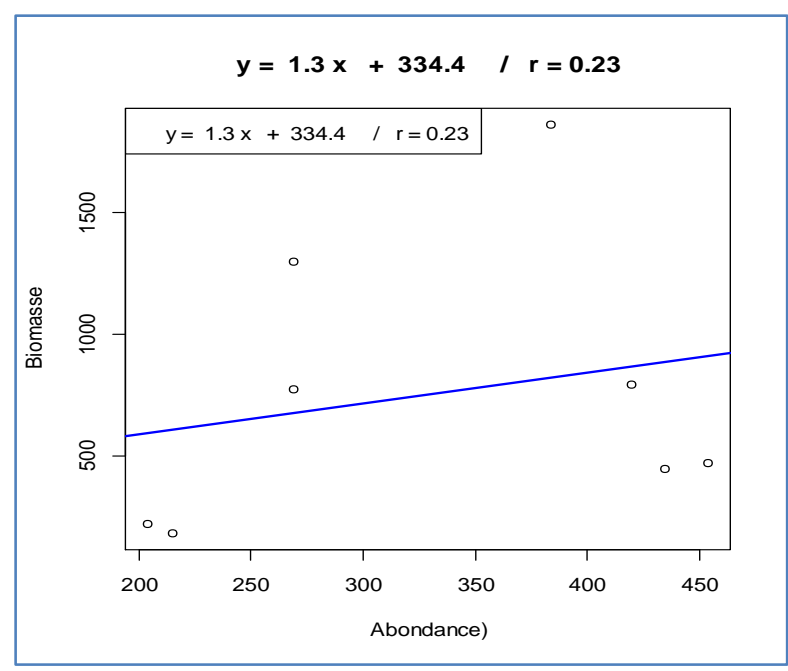

Fig-10: Relationship between Biomass and the relative abundance of macroalgae by site and season of the northern coast of Senegal

\section{DISCUSSION}

Twelve species of macroalgae were identified based on the field survey data collected for 2 years from April 2017 to May 2019 in the northern coast of Senegal. These species belonged to 3 classes, 8 families and 10 genera. The region of Brittany is more abundant in macroalgae than the northern coast of Senegal, if we consider the results of $[15,11]$. This flora is not very diversified compared to that of the center which has 98 species [27], the small coast which has 242 species [23] and the islands of Dakar which has 38 species [19].
All the species were found at Yoff and Kayar while any species was recorded in the others locations (Mboro, Loumpoul, Saint-Louis). In these locations, the substratum is exclusively formed by sandy soil which might be related to the absence of seaweed in this part.

It suggests that in the intertidal zone of the northern coast of Senegal, the distribution and abundance of macroalgae are influenced by the substrates and exposure condition. Substrates are important components that play role in the growth and presence of macroalgae $[31,9,5,21,20]$.

This study highlighted that most of species had low frequency which supports [7] who observed that the macroalgae in the northern coast of Senegal was accidental with a relative frequency under $25 \%$. Among the recorded species, Meristotheca senegalensis, Ceramium rubrum var. pacificum, Caulacanthus ustulatus and Dictyota dichotoma are the most common species.

According to the locality, Ceramium rubrum var. pacificum was the most encountered species in Kayar while Meristotheca senegalensis was the most frequent species at Yoff.

During the present investigation it was observed that the biomass and the density of seaweed were higher during the warm-season. Accoring to [1, 18 , most of the macroalgae have a preference for relatively warm waters $\left(25^{\circ} \mathrm{C}\right)$.

On the other hand, species such as Gymnogongrus crenulatus, Dictyota dichotoma and Bryopsis plumosa are more abundant during cold-season. Besides, [14] showed that Dictyota dichotoma and Bryopsis plumosa proliferation are occurring during summer under the Mediterranean conditions. 
Despite the greater diversity of species encountered at Yoff, the highest abundance and density was recorded at Kayar mainly because of Ceramium rubrum var. pacificum proliferation. The abundance of the genius Ceramium was also reported by [13] in the Mediterranean Sea during spring.

During the warm-season 2017 and 2018 the highest density of seaweed was recorded at Kayar with respectively 454 and 435 individuals.

Underexploited in Senegal, seaweed nonetheless represents a source of economic and social value for the populations living along the country's coast. The study showed that the quantity of macroalgae harvested along Senegalese largest coast is low under 50 g. $\mathrm{m}^{-2}$ compared to Ngor bay where the quantity of biomass per square meter is estimated [27] to $3310 \mathrm{~g} \cdot \mathrm{m}^{-2}$. It appeared from this study that both density and biomass were most abundant to warm-season compared to cold-season. It may result from the abundance of succulent lamellar species such as Meristotheca senegalensis during the warm-season.

\section{CONCLUSION}

This work was undertaken with the aim of better knowing and understanding the dynamics of the quantity of macroalgae available in the north coast of Senegal. It emerges from this study that 12 species of algae distributed in 3 classes, 10 genera and 08 families have been recorded in the north coast of Senegal. Ceramium rubrum var. pacificum (5.8\% of quadrats) and Caulacanthus ustulatus (4.8\% of quadrats) are the most frequent species in the area, respectively in the hot and cold season. Ceramium rubrum var. pacificum is the most abundant and dense species in terms of number of individuals but the Meristotheca senegalensis has the highest biomass with: 1682 grams in 2017 or $33.9 \mathrm{~g} / \mathrm{m}^{2}$ and 1170 grams in 2018 harvested or $23,633.9 \mathrm{~g} / \mathrm{m}^{2}$ in an area of $49.5 \mathrm{~m}^{2}$.

\section{ACKNOWLEDGMENTS}

We are thankful to the NGO OCEANIUM for providing us with divers and complete equipment for this work.

\section{Conflict of Interest}

The authors hereby declare that there is no conflict of interest.

\section{REFERENCES}

1. Billard R. Les carpes biologie et élevage: l'écosystème aquatique et la qualité des eaux. Ed. Bordas.1982, 374.

2. Bodard M, Mollion J. La végétation infralittorale de la petite côte Sénégalaise. Soc. Phycol. De France, Bull. 1974; 19.
3. Bodard M. La végétation infralittorale de la petite côte sénégalaise.

4. Boudouresque CF, Blanfuné A, Fernandez C, Lejeusne C, Pérez T, Ruitton S, Thibault D, Thibaut $\mathrm{T}$, Verlaque M. Marine biodiversity-warming vs. biological invasions and overfishing in the Mediterranean Sea: take care, 'One Train can hide another'.

5. Boudouresque CF. Groupes écologiques d'algues marines et phytocénoses benthiques en Méditerranée nord-occidentale: une revue. Giornale botanico italiano. 1984;118(2):7-42.

6. Brault D. Actualités de la filière algues. Algorythme. 1997;36.

7. Dajoz R. Précis d'écologie. Ed. Bordas, Paris. 1985; 505.

8. Dangeard P. Algues de la presqu'île du Cap Vert (Dakar) et ses environs. Le Botaniste. 1952;36:195-326.

9. Dawes CJ, Mathieson AC. The Seaweeds of Florida. The University Press of Florida: Gainesville, FL; 2008; 80.

10. Delepine R. Rôle des algues marines dans l'économie régionale de l'océan indien occidental. Paris. ORSTOM. 1976; 47 : 285-292

11. Delepine $\mathrm{R}$, Boudouresque $\mathrm{CF}$, frada-orestano $\mathrm{C}$, Noailles MC, ASensi A. Algues et autres végétaux marins. Biogéographie et Ecologie Benthiques B.V.M, Université P. et M. Curie Paris; 1985, France

12. Demoulain G, Leymergie C. Les algues, le trésor de la mer. Haute école de santé Genéve. 2009; 7.

13. De Reviers B. "Biologie et phylogénie des algues". Belin Sup. Tome 1, collection Belin Sup Science, Paris; 2002.

14. De Reviers B. "Biologie et phylogénie des algues". Belin Sup. Tome 2, collection Belin Sup Science, Paris; 2003.

15. Derrien-Courtel S, Catherine E, Le Gal A. Suivi stationnel des roches subtidales de la région de Bretagne. Rapport 1.2. Edition; 2012.

16. Diaw AT. Morphométrie du littoral sénégalais et gambien. Notes Africaines, Dakar. 1984-183: 58-63.

17. Diaw AT, Ba A, Bouland P, Diouf PS, Lake LA, Mbow MA, Ndiaye P, Thiam MD. Gestion des ressources côtières et littorales du Sénégal, l'Atelier de Gorée 27-29 Juillet 1992. UICN, Gland, Suisse, x $+484 \mathrm{pp}$.

18. Diaz-mur P. Ignacio B. Algues des roches couvertes de sable de la péninsule ibérique de l'atlantique. Partie 2. Palmariales, Ceramiales (Hors Rhodomelaceae), Gelidiales, Gigartinales, Rhodymeniales et Scytothamnales. Espagne. Cryptogamie, Algologie. 2014 35(2): 157-199.

19. Diedhiou I. Contribution à la connaissance de la biodiversité des algues macrophytes marines du Sénégal, cas des îles de Dakar: Gorée, Madeleines, Ngor et Yoff Tonghor. Mémoire de master II. 
Faculté des Sciences et techniques, Université Cheikh Anta Diop, DAKAR. 2010; 42.

20. Dizerbo AH. Algues marines Quelques aspects de la végétation des Algues marines supérieures du Massif Armoricain. rev. trav. off. pêches marit. 1947-1949. T. XV. f'Asc.1.4. N57 60

21. Feldmann J, L'hardy-halos M.-TH. La multiplication végétative chez les Algues: ses principaux aspects morphologiques, Bulletin de la Société Botanique de France.1977 ; 124: 13-41.

22. Gueye MF, Bodian MY, Mbaye MS, Sene G, Noba $\mathrm{K}$. Analyse de la flore des macroalgues de trois sites marins de Dakar (PNIM, Soumbédioune et Terrou-bi) au Sénégal. International Journal of Biological and Chemical Sciences. 2019;13(2):634-42.

23. Harper JT, Garbary DJ. Marine Algae of Northern Senegal: the flora and its biogeography. Botanica marina. 1997;40(1-6):129-38.

24. Marfaing H. Qualités nutritionnelles des algues, leur présent et futur sur la scène alimentaire. Cahiers de Nutrition et de Diététique. 2017 Nov 1;52(5):257-68.

25. MEPN. Rapport national sur l'état de l'environnement marin et côtier. Senegal. 2010; 70.

26. Molnar M, Clarke-Murray C, Whitworth J. Marine and Coastal Ecosystem Services: A Report on Ecosystems Services in the Pacific North Coast Integrated Management Area (PNCIMA) on the British Columbia Coast. David Suzuki Foundation; 2000.
27. Ndao M, Bodian MY, Noba K. Diversité des algues macrophytes marines du littoral centre du Sénégal, Afrique science. 2017; 13(3): 287-296.

28. Perez R. Ces algues qui nous entourent. Conception actuelle, rôle dans la biosphère, utilisation, culture. Edition IFREMER. 1997: 272.

29. Person J. Algues, filières du futur. Livre turquoise, Adebiotech; 2011: 161.

30. Prathep A. Spatial and temporal variations in diversity and percentage cover of macroalgae at sirinart marine national park, Phuket province, Thaïland, Science Asia.2005; 31: 225-233

31. Robuchon M. Etude spatio-temporelle de la biodiversité des forêts de laminaires des côtes bretonnes par une approche intégrée de génétique des populations et d'écologie des communautés, Thèse de Doctorat, Ecologie et évolution, Muséum national d'histoire Naturelle. 2014: 134.

32. Camara MMB. Quelle gestion des pêches artisanales en Afrique de l'Ouest? Etude de la complexité de l'espace halieutique en zone littorale Sénégalaise, Thèse de doctorat de troisième cycle, Faculté des lettres et sciences humaines, Université Cheikh Anta Diop de DAKAR; 339.

33. L'hardy-halos M.-TH, Castric-fey A, Girard-descatoire A. Lafargue f. Recherches en scaphandre autonome sur le peuplement végétal de l'infralittoral rocheux: I 'Archipel de Glénan. Bulletin de la Société Scientifique de Bretagne. 1973 ; 48: 103-128. 